\title{
SOME STUDIES ON PASTEURELLA MULTOCIDA AS A CAUSATIVE AGENT OF MASTITIS IN DAIRY COWS AND EWES
}

\author{
HANAA A.E. ASFOUR ${ }^{1}$; ABEER M. ANWER ${ }^{2}$; A.M. NABEEH ${ }^{1}$ and ABEER E. EL-METWALLY ${ }^{3}$ \\ ${ }^{1}$ Mastitis and Neonatal Diseases Department, Animal Reproduction Research Institute (ARRI), Giza, Egypt. \\ ${ }^{2}$ Immunobiology and Immunopharmacology Unit, Animal Reproduction Research Institute (ARRI), Giza, Egypt. \\ ${ }^{3}$ Pathology Department, Animal Reproduction Research Institute (ARRI), Giza, Egypt.
}

Received: 6 June 2016; Accepted: 31 July 2016

\begin{abstract}
ABSTERACT
A total of 233 mastitic milk samples (151 cows and 82 ewes) and 90 mammary gland tissue samples (56 cows and 34 ewes) were collected from different Egyptian Governorates for P. multocida investigation as one of mastitis causing pathogens and its effect on the mammary gland tissues. The isolated P. multocida from clinical mastitic milk was slightly higher than that from subclinical form in both cows and ewes (15.3\% versus $13.1 \%$ and $27.3 \%$ versus $26.7 \%$, respectively) and it was isolated from the udder tissues of both cows and ewes with percentages of (17.85\%) and (23.52\%), respectively. Enzyme linked immunosorbent assay (ELISA) was used as confirmatory, rapid and reliable test for detection of $P$. multocida antibodies in the tested milk samples and they were detected in mastitic cow's and ewe's milk whey in (17.2\%) and (34.2\%), respectively. The antibiogram profile of P. multocida was studied for detection of its susceptibility to 15 different antibiotics to detect the drug of choice for its treatment. $P$. multocida isolated from cow's milk showed more resistance to various antibiotics than that isolated from ewe's milk. The DNA integrity of mammary gland tissue cells was detected using comet assay and the percentage of DNA damage was significantly elevated in case of P. multocida infected mammary gland $(\mathrm{P}<0.05)$. In addition, the histopathological findings of $P$. multocida infected udder showed focal and/or diffuse chronic lymphocytic mastitis with an extensive degeneration and necrosis of the alveolar epithelium as well as interstitial tissue. Most of the mammary alveoli were filled with basophilic bacterial colonies with bipolar bodies positively stained by methylene blue and Giemsa stains. Cytological evaluation was conducted on all udder tissue samples and $16 / 18$ positive cases $(88.8 \%)$ were correlated with their histopathological examination. Histochemically, tissue sections from infected udder showed weak or no alkaline phosphatase activity and density of protein staining. It was concluded that $P$. multocida should be considered as an important sharing etiological agent of mastitis in both cows and ewes (especially in ewes) and associated with significant histopathological alterations in the glandular tissue structure. ELISA was considered as a quick and reliable technique for detection of P. multocida infection in the mammary gland especially in the un-vaccinated farms beside the traditional cultural method. The cytological interpretation was quiet helpful in rapid screening of the mammary gland affections.
\end{abstract}

Key words: Pasteurella multocida, cows, ewes, mastitic milk, mammary gland tissues, ELISA, comet assay, antibiogram, histopathology, histochemical studies, cytological smear.

\section{INTRODUCTION}

Mastitis is a common disease of ruminants accompanied with physical, chemical, bacteriological changes in milk and pathological alterations in glandular tissues (Abba et al., 2014). It is still one of the most important diseases with serious and heavy economic losses because it can reduce milk quality, production, suitability for human consumption and eventually limit the profitability of dairy farmers (Owens et al., 1997).

Corresponding author: Dr. HANAA A.E. ASFOUR

E-mail address: hanaaasfour@yahoo.com

Present address: Mastitis and Neonatal Diseases Department,

Animal Reproduction Research Institute (ARRI), Giza, Egypt.
Ovine mastitis is a widespread disease of dairy ewes with significant adverse production effects and is mainly caused by bacteria that invade and multiply in the mammary gland tissue. It has not been studied as extensively as that in cows; consequently mechanisms of its pathogenesis have not been clarified (Mavrogianni et al., 2006). The annual incidence of clinical mastitis in small ruminants was generally lower than $5 \%$, but this incidence can increase sporadically (Ahmadi et al., 2014).

The family Pasteurellaceae contains Gram-negative, facultative anaerobic and fermentative bacteria of the genera Pasteurella, Haemophilus, and Actinobacillus. Approximately 20 different species of the genus Pasteurella have been identified using phenotypic and genetic analyses but $P$. multocida and $P$. haemolytica 
are the most prominent pathogens in domestic animals causing severe diseases and major economic losses in the cattle, swine, sheep, and poultry industries (Confer, 1993). P. multocida is a non-spore forming, non-motile, small Gram-negative rods or coccobacilli and it is an important animal pathogen which causes mastitis, pneumonic pasteurellosis. Mastitis was severe, resulted in abnormal secretion, atrophy, and fibrosis of the affected quarter. The general herd management was below average, the environment insanitary and the cattle in poor physical condition (Rimler and Rhoades, 1989).

P. multocida and M. haemolytica can cause mastitis in sheep more commonly than in goats (Ajuwape et $a l ., 2005)$. The source of these organisms is usually the upper respiratory system of nursing kids. These pathogens were most often associated with per-acute mastitis and were more common cause of gangrenous mastitis than S.aureus in sheep under some management conditions (Eugene, 2007).

P. multocida causes haemorrhagic septicaemia (HS) in Asian and African countries which is a major epizootic disease of cattle with heavy morbidity and mortality. Being simple, rapid, inexpensive and easy for automation, ELISA has emerged as an important tool for diagnosis as well as monitoring the immune status of animals vaccinated against $\mathrm{HS}$ in laboratories (Kharb, 2015).

Diagnostic cytology is a quick, inexpensive and easily repeatable technique requiring minimal of sophisticated instruments (Cohen et al., 2003) and it has recently been employed for diagnosis of some diseases, when applied to mammary gland lesions, the method showed good diagnostic accuracy (Sangha et al., 2011).

Very little recorded researches on the role of $P$. multocida as mastitis pathogen and its pathological effect on the mammary gland, so the aims of this study were to: 1) investigate the incidence of $P$. multocida in mastitic milk and mammary gland tissues in cows and ewes by traditional culture methods and by using ELISA as a rapid and less expensive technique for detection of its antibodies in milk whey of mastitic un-vaccinated animals. 2) Detect the antimicrobial effect of several antibiotics on the isolated strains of P. multocida. 3) Detect the effect of $P$. multocida on the infected mammary gland cell's DNA integrity. 4) Spotlight on the diagnosis of P. multocida mammary gland lesions on the basis of histopathological picture and to compare with the relative efficacy of diagnostic cytology as well as histochemical examination.

\section{MATERIALS AND METHODS}

\section{Collection of samples:}

1.1. Milk samples: A total number of 233 composite milk samples were collected from different Egyptian
Governorates (Giza, El-Behira, Alexandria, ElGharbia, Kafr El-Sheikh, El-Sharkia, Port Saied and Beni-Suief); from dairy cows and ewes (151 and 82 samples, respectively) using California mastitis test (CMT) for detection of subclinical mastitis (SCM) and physical examination for detection of clinical mastitis. The samples were collected under complete aseptic conditions. The milk sample was preincubated at $37^{\circ} \mathrm{C} / 12-18 \mathrm{~h}$ then $20 \mu \mathrm{l}$ of the incubated sample was streaked onto brain heart infusion agar, blood agar (with 7\% sheep blood), MacConkey agar, Mannitol salt agar and Edward's media (Himedia, Mumbai, India) for detection of the most common bacteria present in milk under study. Bacterial colonies were described for their morphological characteristic appearance and hemolytic activity, followed by Gram staining and motility test then were subjected to further identifications according to Quinn et al. (2011). Suspected colonies of $P$. multocida from the initial cultures were re-cultured on brain heart infusion agar and blood agar (round, smooth, mucoid and nonhemolytic colonies were observed) and re-incubated at $37{ }^{\circ} \mathrm{C}$ for $48 \mathrm{~h}$, then stained films with Leishman's stain showed bipolar coccoid organisms. Growth test on MacConkey agar medium was negative. Further biochemical identifications for $P$. multocida were done.

\subsection{Mammary gland tissue samples:}

Ninety tissue samples from mammary glands (56 cows and 34 ewes) were collected from adult slaughtered animals, from Cairo and Giza abattoirs, Egypt. The udder tissue samples were randomly collected among the slaughtered animals and were visually examined for gross lesions. Then each tissue sample was divided into four parts, one part was put in a small polyethylene bag in an ice box under aseptic conditions for bacteriological examination. The second part was immersed in $10 \%$ neutral formalin solution for histopathological evaluation and the third one kept for cytological smear preparation. The last one was kept for detection of mammary gland cell's DNA integrity using comet assay.

\section{Detection of $P$. multocida antibodies in milk} whey using ELISA.

Indirect ELISA was used for detection of $P$. multocida antibodies in the tested milk whey samples of both cows and ewes.

2.1. Preparation of sonicated $\boldsymbol{P}$. multocida antigen: A confirmed $P$. multocida isolate was used for preparation of the antigen according to Afzal et al. (1992) and the protein content in the extract was measured (Henery, 1974).

2.2. Enzyme-linked immunosorbent assay: An indirect ELISA was performed using prepared diluted antigen $(560 \mu \mathrm{g} / \mathrm{ml})$ in sodium carbonate coating buffer as described previously by Muneer and Afzal (1989) to detect the antibodies against P. multocida 
with some modifications. The conjugate used was protein A-peroxidase from S.aureus (1:80,000 in PBS-T, Sigma, Germany) due to unavailability of anti-ovine IgG. Optical densities were recorded using ELISA reader at $492 \mathrm{~nm}$. Control negative samples were used to detect the cutoff point. The ELISA reading that $\geq$ double figure of the reading of control negative was considered as positive result.

3. Nitric oxide level. The measurement of $\mathrm{NO}$ was assessed according to the assay described by Rajarman et al. (1998).

4. Lysozyme activity in milk whey. Lysozyme activity was measured according to Schultz (1987).

5. Antibiotic sensitivity testing of the isolates: antimicrobial susceptibility of $23 P$. multocida strains (15 cow's and 8 ewe's strains) to 15 antibiotics using disk diffusion technique was performed according to the National Committee for Clinical Laboratory Standards (NCCLS, 2008) on Mueller Hinton agar using commercially available antimicrobial test discs [ciprofloxacin; CIP $(5 \mu \mathrm{g})$, norfloxacin; NOR $(10 \mu \mathrm{g})$, levofloxacin; $\operatorname{LEV}(5 \mu \mathrm{g})$, ofloxacin; OFX $(5 \mu \mathrm{g})$, chloramphinicol; C $(30 \mu \mathrm{g})$, amoxicillin-clavulanic acid; AMC (30 $\mathrm{g})$, amoxicillin; AMX (25 $\mu \mathrm{g})$, ampicillin; AM $(10 \mu \mathrm{g})$, penicillin; $\mathrm{P}(10 \mathrm{U})$, cefoperazone-sulbactam; CES (10/10 $\mu \mathrm{g})$, tetracycline; TE $(30 \mu \mathrm{g})$, neomycin; $\mathrm{N}(30 \mu \mathrm{g})$, gentamycin; CN (10 $\mu \mathrm{g})$, streptomycin; S $(10 \mu \mathrm{g})$ and cefoquinom; CEQ $(30 \mu \mathrm{g})]$. Results were recorded by measuring the inhibition zones and scored as sensitive, intermediate susceptibility and resistant according to the NCCLS recommendations.

6. Detection of mammary gland cell's DNA integrity using comet assay. Mammary gland cell's DNA damage was determined according to Singh et al. (1988). Out of 100 randomly selected nuclei were photographed and scanned for detection of tail length, the percentage of DNA in the tail and the tail moment.

\section{Histopathological examination of mammary} gland tissues.

7.1. Tissue preparation for histopathological examination: Each tissue sample was fixed in $10 \%$ neutral formalin solution. The fixed specimens were trimmed, washed, dehydrated in ascending grades of alcohol, cleared in xylene and embedded in paraffin. The embedded samples were sectioned at 3-5 $\mu \mathrm{m}$ thickness, stained with H\&E stain as well as Masson's Trichrome, methylene blue and Giemsa were used as special stains according to Suvarna et al. (2013).

\subsection{Cytological smear preparation:}

It was applied on 90 freshly mammary gland tissue samples of cows and ewes according to Pawar et al. (2015). The collected tissues were cut to get a fresh uncontaminated surface and then blotted many times to make it dry. To minimize microbial contamination, the area of the lesion was cleaned with sterile cotton swab moistened with saline solution. Do not use water to prevent osmosis that induced cell rupture. A clean glass slide was pressed against the dried tissue surface and the cellular smears were spread then stained with Leishman stain.

7.3. Histochemical Investigations: Alkaline phosphatase activity (AP) and density of protein staining (mercury-bromophenol blue techniques) in mammary epithelial cells were determined according to Hussain et al. (2013).

8. Statistical Analysis: Data were subjected to statistical analysis according to Sendecor and Cochran (1989) by one way ANOVA employing a completely randomized design at $\mathrm{P}<0.05$.

\section{RESULTS}

Table 1: Incidence of $P$. multocida infection in cow's and ewe's milk samples by culture method

\begin{tabular}{|c|c|c|c|c|}
\hline \multirow[t]{2}{*}{ Isolated bacteria } & \multicolumn{2}{|c|}{ Cow's milk (151) } & \multicolumn{2}{|c|}{ Ewe's milk (82) } \\
\hline & $\begin{array}{c}\text { Clinical } \\
\text { mastitic } \\
\text { milk (59) }\end{array}$ & $\begin{array}{c}\text { Subclinical } \\
\text { mastitic } \\
\text { milk }(92) \\
\end{array}$ & $\begin{array}{c}\text { Clinical } \\
\text { mastitic } \\
\text { milk (22) }\end{array}$ & $\begin{array}{c}\text { Subclinical } \\
\text { mastitic milk (60) }\end{array}$ \\
\hline Single infection of $P$. multocida & $2(3.4 \%)$ & - & $3(13.6 \%)$ & $4(6.7 \%)$ \\
\hline \multicolumn{5}{|l|}{ Mixed infection } \\
\hline P. multocida + S.aureus & - & $2(2.2 \%)$ & - & $2(3.3 \%)$ \\
\hline P. multocida + S.aureus + E.coli & $5(8.5 \%)$ & $6(6.5 \%)$ & - & - \\
\hline P. multocida +S.aureus + environmental streptococci & $2(3.4 \%)$ & $1(1.1 \%)$ & - & - \\
\hline P. multocida + CNS & - & - & $3(13.6 \%)$ & $5(8.3 \%)$ \\
\hline P. multocida + CNS + E.coli & - & $3(3.3 \%)$ & - & $5(8.3 \%)$ \\
\hline Total no. of mixed infection (\%) & $7(11.9 \%)$ & $12(13.1 \%)$ & $3(13.6 \%)$ & $12(20 \%)$ \\
\hline \multirow[t]{2}{*}{ Total no. (\%) } & $9(15.3 \%)$ & $12(13.1 \%)$ & $6(27.3 \%)$ & $16(26.7 \%)$ \\
\hline & \multicolumn{2}{|c|}{$21(13.9 \%)$} & \multicolumn{2}{|c|}{$22(26.8 \%)$} \\
\hline
\end{tabular}

$\%$ was calculated according to the type of mastitic milk and the total \% was calculated according to the total no. of milk samples of each animal species. 
Table (1) illustrated that $P$. multocida was isolated as single and mixed infection (mainly with S.aureus followed by E.coli then environmental streptococci) with a percentage of $3.4 \%$ ( 2 samples) and $11.9 \%$ (7 samples) in clinical mastitic cows' milk, respectively. While it was isolated from 12 subclinical mastitic cows' milk samples in a mixed form only (13.1\%). Moreover, P. multocida was isolated from ewes' clinical mastitic milk as single infection (3/22) with $\%$ of $(13.6 \%)$ and $3 / 22$ in a mixed form with CNS (13.6\%). It was also isolated from subclinical mastitic ewes' milk in single infection $(4 / 60 ; 6.7 \%)$ and as mixed infection with CNS, E.coli and S.aureus with total $\%$ of $20 \%$ (12/60). Generally, it was noticed that $P$. multocida was isolated from clinical mastitis slightly higher than that from subclinical form in both cows and ewes (15.3\% versus $13.1 \%$ and $27.3 \%$ versus $26.7 \%$, respectively). It was announced that $P$. multocida totally isolated from ewe's mastitic milk with a higher rate than that of cows $(26.8 \%$ versus $13.9 \%$, respectively).

Table 2: Detection of $P$. multocida antibodies in cow's and ewe's milk samples using ELISA

\begin{tabular}{lcccc}
\hline \multirow{2}{*}{ ELISA } & \multicolumn{2}{c}{ Cow's milk (151) } & \multicolumn{2}{c}{ Ewe's milk (82) } \\
\cline { 2 - 5 } & $\begin{array}{c}\text { Clinical mastitic } \\
\text { milk (59) }\end{array}$ & $\begin{array}{c}\text { Subclinical mastitic } \\
\text { milk (92) }\end{array}$ & $\begin{array}{c}\text { Clinical mastitic milk } \\
(22)\end{array}$ & $\begin{array}{c}\text { Subclinical mastitic } \\
\text { milk (60) }\end{array}$ \\
\hline Positive & $12(20.3 \%)$ & $14(15.2 \%)$ & $8(36.4 \%)$ & $20(33.3 \%)$ \\
\hline Total & \multicolumn{2}{c}{$26(17.2 \%)$} & $28(34.2 \%)$ \\
\hline
\end{tabular}

Tables (2) showed that $P$. multocida antibodies were detected in mastitic cow's milk in 26 out of 151 of the samples $(17.2 \%)$, while higher \% was detected in ewe's milk $(28 / 82 ; 34.2 \%)$.

Table 3: Comparison between incidence of $P$. multocida in milk samples by cultural method and ELISA in diagnosis

\begin{tabular}{cccccc}
\hline Animal species & \multirow{2}{*}{$\begin{array}{c}\text { No. of examined } \\
\text { Milk samples }\end{array}$} & \multicolumn{2}{c}{ Cultural method } & \multicolumn{2}{c}{ ELISA } \\
\cline { 3 - 6 } & $(151)$ & No. & $\%$ & No. & $\%$ \\
\hline Cows & $(82)$ & 21 & $(13.9 \%)$ & 26 & $(17.2 \%)$ \\
\hline ewes & & 22 & $(26.8 \%)$ & 28 & $(34.2 \%)$ \\
\hline
\end{tabular}

Table (3) showed that incidence of P. multocida in milk samples by cultural method was lower than that of ELISA technique in diagnosis; (13.9\%) versus (17. 2\%) in cow's milk and (26.8\%) versus (34.2\%) in ewe's milk.

Table 4: Nitric oxide level and lysozyme activity in cow's and ewe's mastitic milk samples positive for $P$. multocida infection (Mean \pm SE).

Animal species

Grade of mastitis

\begin{tabular}{cccc}
\hline \multicolumn{2}{c}{ Clinical mastitis } & \multicolumn{2}{c}{ subclinical mastitis } \\
\hline NO $($ umol $/ \mathrm{ml})$ & lysozyme $(\mathbf{u g} / \mathrm{ml})$ & NO & lysozyme \\
\hline $274 \pm 25.9 * * *$ & $205.5 \pm 25 * * *$ & $105.3 \pm 10.1$ & $\mathbf{8 9 . 6 \pm 5 . 8}$ \\
\hline $242.8 \pm 18.8 * * *$ & $175.1 \pm 17.9 * *$ & $101.9 \pm 12.4$ & $97.9 \pm 5.78$ \\
\hline
\end{tabular}

Table (4) illustrated that both NO and lysozyme were significantly increased according to the grade of mastitis (higher in clinical form than subclinical form) in both cows and ewes. 
Table 5: Incidence of $P$. multocida infection in cow's and ewe's mammary gland tissue samples.

\begin{tabular}{lcc}
\hline Isolated bacteria & $\begin{array}{c}\text { Cow's mammary gland } \\
\text { tissue samples (56) }\end{array}$ & $\begin{array}{c}\text { Ewe's mammary gland } \\
\text { tissue samples }(34)\end{array}$ \\
\hline Single infection of $P$. multocida & $4(7.14 \%)$ & $4(11.76 \%)$ \\
\hline $\begin{array}{l}\text { Mixed infection } \\
\text { P. multocida }+S \text {.aureus }\end{array}$ & $6(10.71 \%)$ & $4(11.76 \%)$ \\
\hline Total & $10(17.85 \%)$ & $\mathbf{8}(23.52 \%)$ \\
\hline
\end{tabular}

Table (5) showed that P. multocida was isolated from mammary gland tissues of both cows and ewes with $\%$ of $(17.85 \%)$ and $(23.52 \%)$, respectively, also the \% of isolation in ewes was higher than that of cow's udder tissues.

Table 6: The effect of $P$. multocida natural infection on mammary gland tissue integrity using comet assay in comparison to the un-infected one.

\begin{tabular}{lcccc}
\hline Type of mammary tissue & $\%$ of damage & Tail Length $(\mathrm{px})$ & $\%$ DNA in Tail & Tail Moment \\
\hline Un-infected udder tissue & $11.2 \pm 0.120$ & $2.71 \pm 0.505$ & $16.9 \pm 1.32$ & $0.531 \pm 0.152$ \\
\hline Mastitic udder tissue & $21.5 \pm 1.44 * *$ & $4.6 \pm 0.353 *$ & $27.4 \pm 1.09 * *$ & $1.68 \pm 0.143 * *$ \\
\hline
\end{tabular}

Table (6) declared that the percentage of damage and DNA \% in comet tail was significantly elevated in case of $P$. multocida infected mammary gland when compared with the uninfected one, $(\mathrm{P}<0.05)$.

The antibiogram profile of 15 representative $P$. multocida strains isolated from infected cows' milk showed that, all of them were highly susceptible to CIP, NOR, LEV, OFX and C (100\%). In declining order only 5 out of 15 strains (33.3\%) were susceptible to CEQ, CEX, AMC, TE, CN and S, while about $10 / 15(66.7 \%)$ were resistant to CEQ, CEX, AMC, TE, CN and S. On the other hand all the tested strains showed complete resistance to AMX, $\mathrm{AM}, \mathrm{P}$ and $\mathrm{N}$.

Antibiotic susceptibility results of 8 representative $P$. multocida strains isolated from ewes' milk showed that they were highly susceptible to CIP, NOR, LEV, OFX, AMC, AMX, TE, and C (100\%). 4 out of 8 $(50 \%)$ strains were susceptible only to $\mathrm{CEX}, \mathrm{CN}$ and AM. On the other hand all the tested strains showed complete resistance to CEQ, P, S and N. From the previous results, it was noticed that, $P$. multocida isolated from cows' milk showed more resistance to various antibiotics than that isolated from ewes' milk.

Histopathological examination was applied on all collected tissue samples. Macroscopically, most of the mammary glands were apparently normal while some cases were pale and fibrosed.

The prominent feature of microscopic examination of the mammary glands of 4 cows and 2 ewes that revealed single $P$. multocida isolates was focal and /or diffuses chronic lymphocytic mastitis in which there was proliferation of intralobular and interlobular fibrous connective tissue accompanied with marked infiltrations of lymphocytes, macrophages and plasma cells (fig. 5). Atrophy and fragmentation of alveoli were observed as well as the alveolar epithelium appeared flattened and granular (fig. $6 a \& b$ ). While other cases showed epithelial vaculations with cystic dilatation of acini. The damaged alveoli were empty or contained mononuclear inflammatory cells and few neutrophils together with desquamated epithelium and fibrin network. Most of the mammary alveoli were diffusely filled with basophilic bipolar coccobacilli of $P$. multocida positively stained by methylene blue and Giemsa stains (fig. 7a) or pink color by H\&E (fig. 7b). Focal epithelial necrosis observed in tissues in most of cases. Corpora amylacea were detected inside acini. The increase of the interstitium was of variable intensity and that confirmed with Masson's Trichrome stain (fig. 8). Moderate hyperplasia of epithelial lining of lactiferous ducts was detected and associated with subepithelial mononuclear cell aggregations as well as lymphocytic exocytosis. Interlobular connective tissue was mild to moderately expanded by edema. Blood vessels showed thickening of their tunica media with vasculitis.

Two cases of single $P$. multocida mastitic ewes showed acute suppurative mastitis that revealed an extensive infiltration of neutrophils and macrophages 
within the alveolar lumen and interstitial connective tissue as well as vacuolar degeneration, desquamation and necrosis of the alveolar epithelium (fig. 9). Most of the mammary alveoli were devoid of milk and filled with bacterial colonies, fibrin network and caseated milk. Focal areas of interstitial haemorrhage were observed. Vasculitis with edema and dilated lymph ducts were detected. While mixed infection $(P$. multocida $+S$.aureus) was detected in 10 cases (6 cows and 4 ewes) that revealed marked chronic mastitis with highly proliferated connective tissue, inflammatory cell infiltrations and hyperplasia of ductular epithelium.

Cytological smear evaluation of inflamed mammary glands revealed bacteria, inflammatory and tissue cells. Mammary epithelial cells showed granular feature. Fourteen cases (10 cows and 4 ewes) as single and mixed infection showed chronic inflammatory character in which there were macrophages, lymphocytes and few neutrophils appeared in the cytological smears. Two cases of ewes revealed dominant degenerative neutrophils; this was considered as an acute suppurative response. Also, the intra and extra-cytoplasmic bipolar coccobacillus bacteria were demonstrated (fig. 10).
The correlation between cytological and histopathological results was also determined. Out of 18 positive $P$. multocida mastitic cases, 16 (88.8\%) tissue samples showed changes by cytological smear evaluation and that came in accordance with their histopathological picture.

The activity of alkaline phosphatase in tissue sections of healthy animals was apparent on the outer boundary of alveolar secretory cells indicating the high activity of mammary gland. While in tissue sections from Pasteurella mastitic animals, few alveoli indicated weak activity of alkaline phosphatase and the most of the alveoli showed disappearance of this enzyme reflecting no activity (fig. 11a \&b).

Similarly, the greatest density of protein staining was found in the thick-walled mammary alveoli with larger cells in normal non mastitic mammary tissues. On the other side, alveoli showed weak or no staining for protein and the connective tissue was increased concomitantly with the regression of the alveoli into the smallest size and reduced frequency of secretory cells in P. multocida mastitic cases (fig. $12 \mathrm{a} \& \mathrm{~b}$ ).
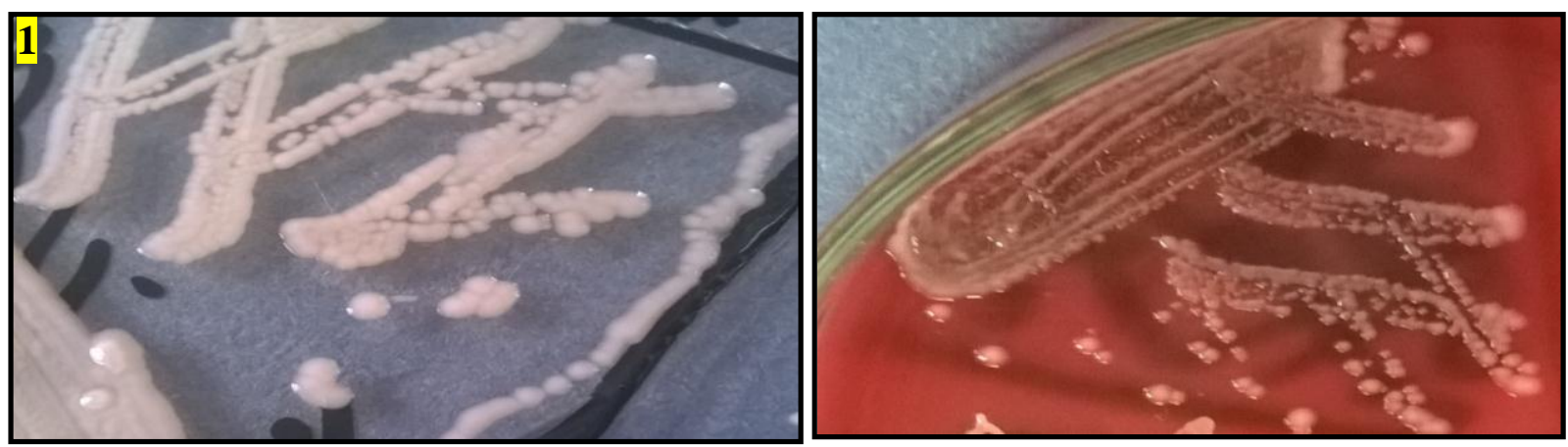

Fig. 1: Colonial morphology of $P$. multocida on brain heart infusion agar (mucoid colonies) and blood agar (non-hemolytic).
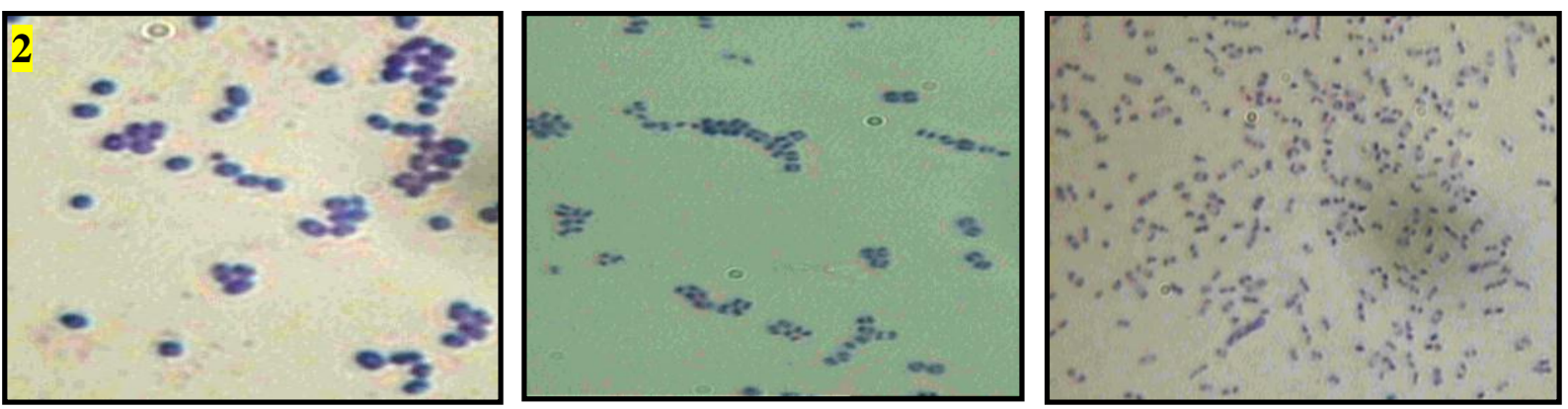

Fig. 2: Microscopical examination of P. multocida isolated from mammary gland tissue and milk samples showed bipolar cocobacillus microorganisms stained with Leishman's stain. 

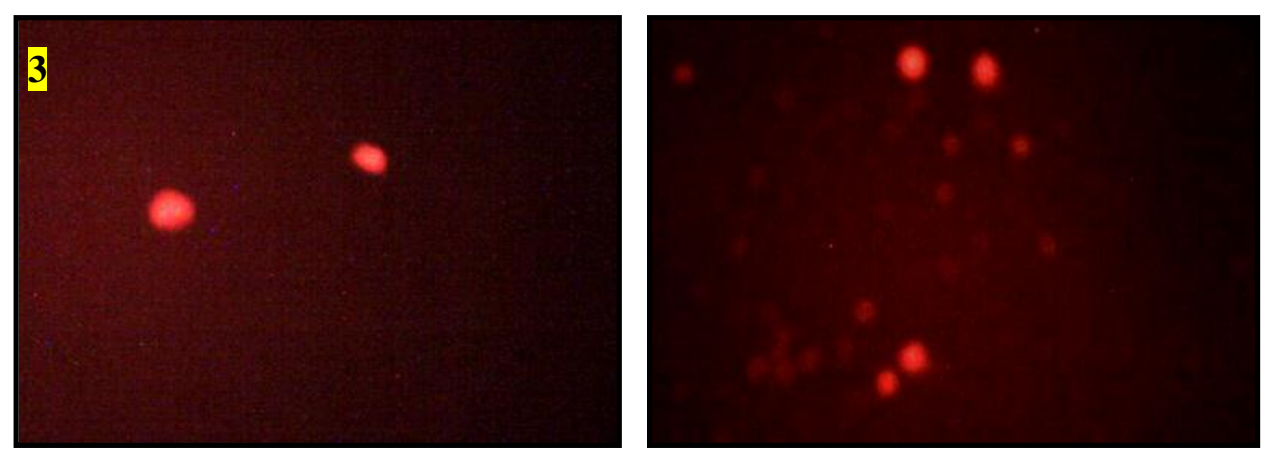

Fig. 3: Undamaged mammary gland cell's DNA in clinically healthy cow measured by the comet assay where DNA remains within the core. The DNA is tightly compressed and maintained the circular disposition of the normal nucleus.
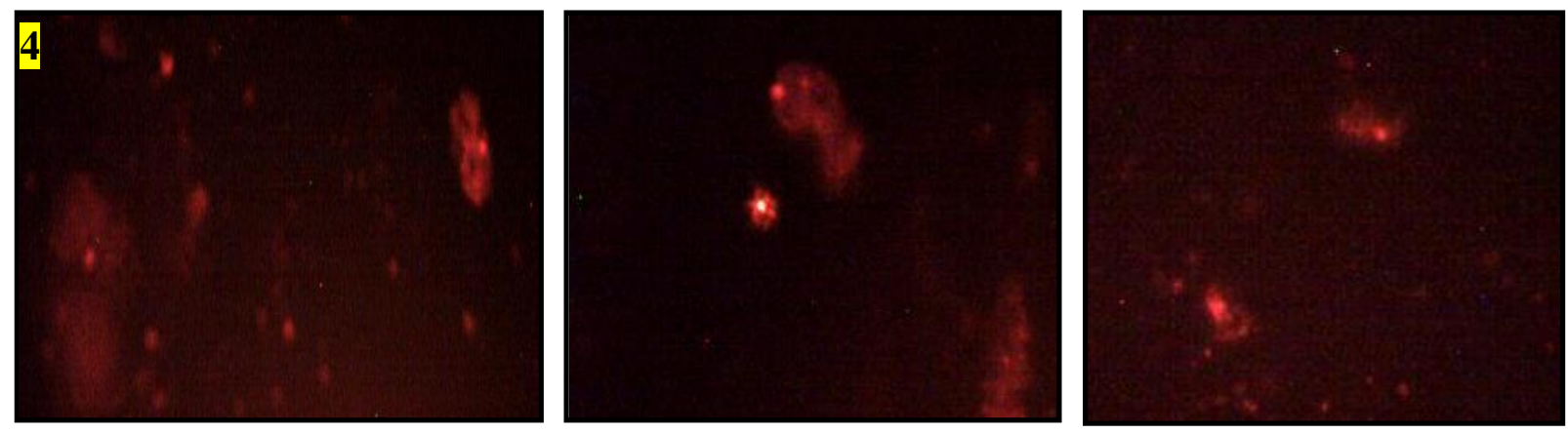

Fig. 4: Severe DNA damage in clinically mastitic mammary gland tissues infected with $P$. multocida measured by the comet assay. The cells were examined by fluorescence microscopy, fluorescent structures corresponding to the stained nuclear DNA. The increase in DNA damage was mostly evidenced by an increase of comet tail.
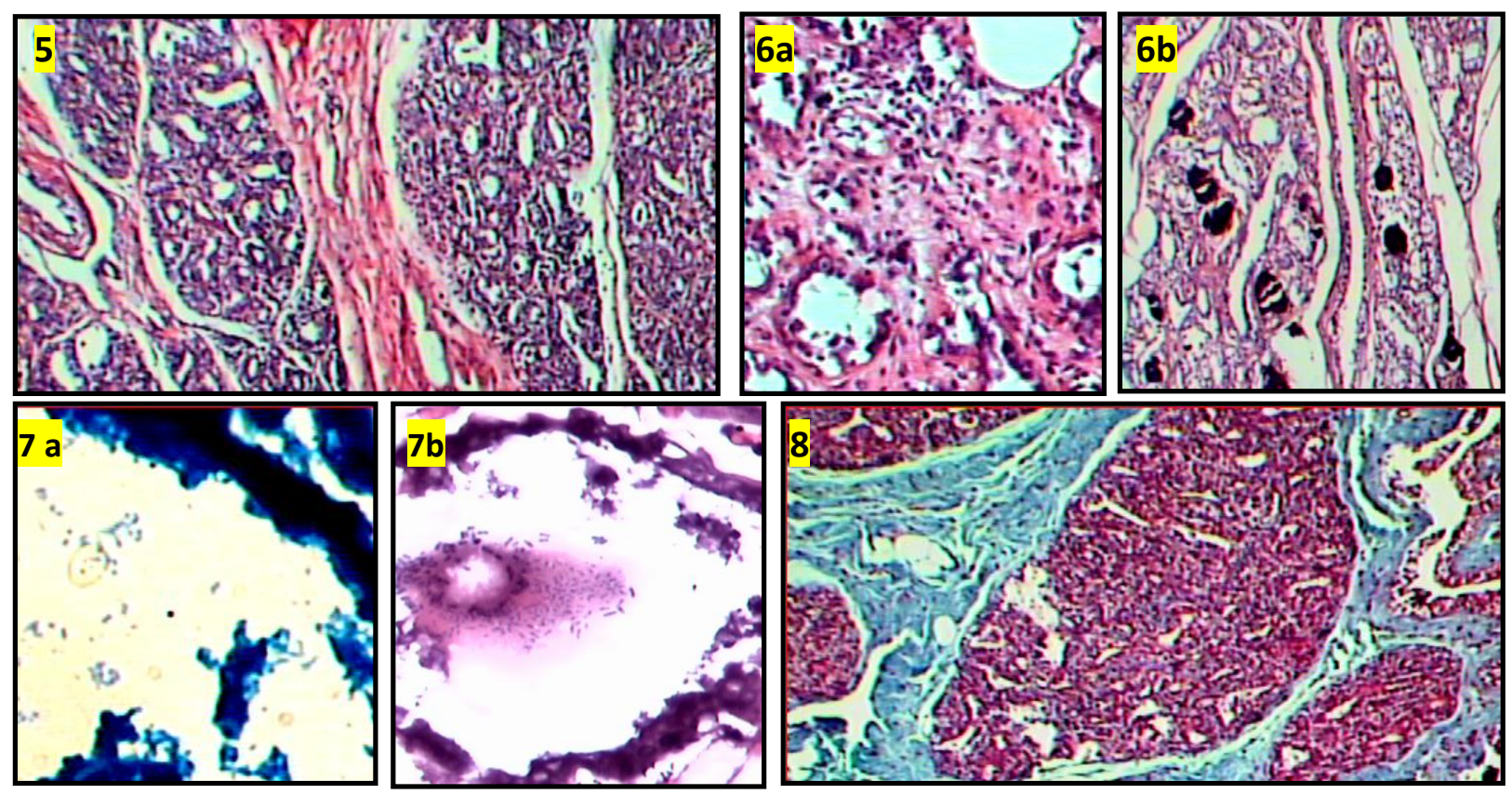

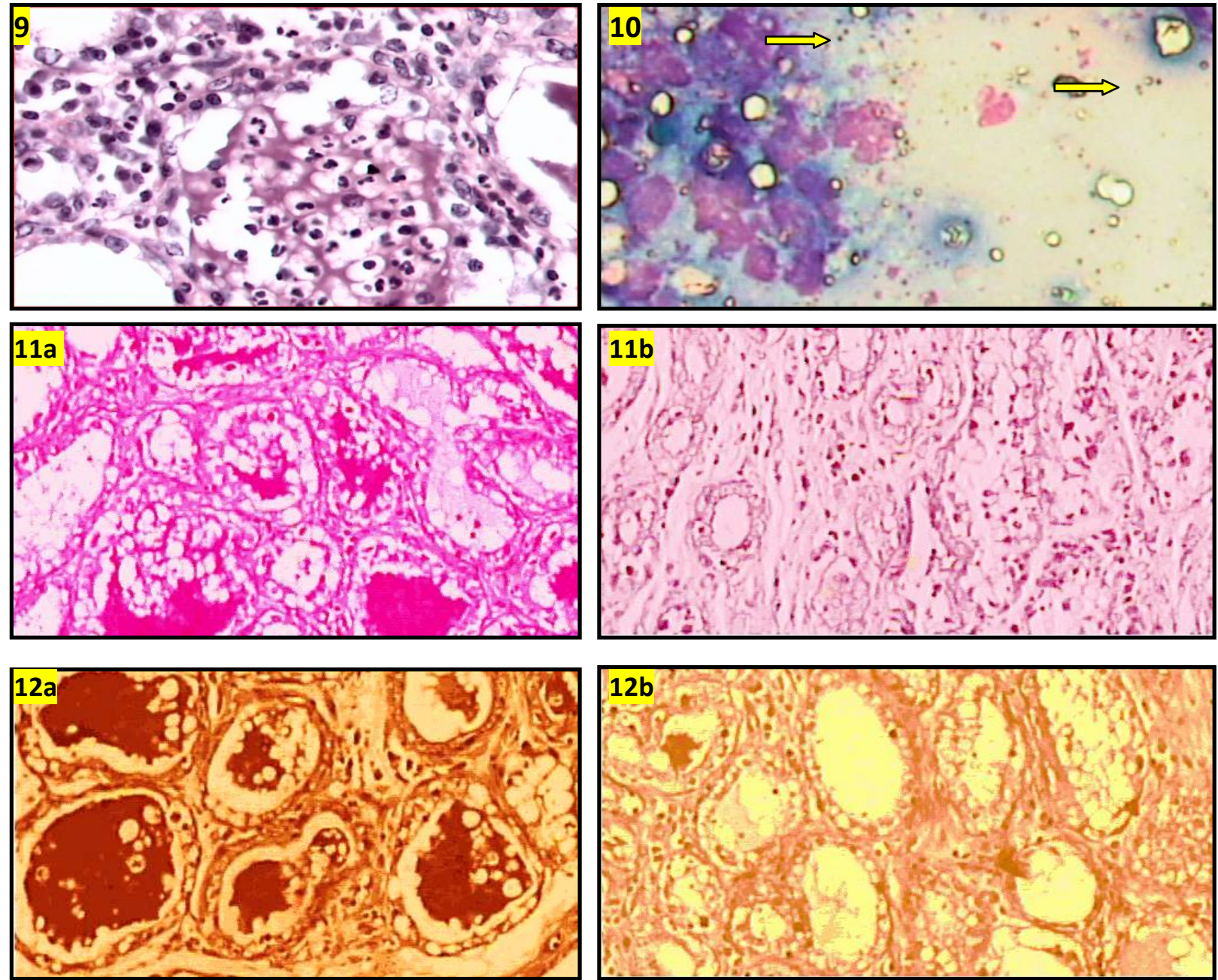

Fig.5: Cow's mammary gland showing chronic lymphocytic mastitis with marked proliferation of fibrous connective tissue (H\&E, X40).

Fig.6a: Ewe's mammary gland showing atrophy and damaged alveoli as well as marked fibrous connective proliferation and mononuclear cell infiltrations (H\&E, X100).

Fig.6b: Ewe's mammary gland showing chronic mastitis associated with the presence of corpora amylacea (H\&E, X40).

Fig.7 a: Cow's mammary gland showing basophilic bipolar coccobacillus bacterial colonies inside damaged alveoli (methylene blue stain, X100).

Fig. 7b: Ewe's mammary gland showing pink bipolar coccobacillus bacterial colonies inside and attached to alveolar epithelium (H\&E, X100).

Fig.8: Cow's mammary gland showing marked proliferation of fibrous connective tissue with atrophied lobules (Masson's Trichrome stain, X40).

Fig.9: Ewe's mammary gland showing acute suppurative mastitis with neutrophils and macrophages infiltration in the mammary acini and interstitial connective tissue as well as desquamated epithelium and cellular debris of necrotic alveolar epithelium (H\&E, X400).

Fig.10: Cytological smear from ewe's mammary gland with acute mastitis showing granular mammary epithelial cells, neutrophils with intra and extracytoplasmic bipolar bacteria (yellow arrows) (Leishman stain, X 1000).

Fig.11a: Section of mammary tissue from healthy cow showing high level of alkaline phosphatase activity (H\&E, X100).

Fig.11b: Section of mammary tissue from $P$. multocida mastitic cow showing no to weak alkaline phosphatase activity (H\&E, X100).

Fig.12a: Section of mammary tissue from healthy cow showing high protein staining (H\&E, X100).

Fig.12b: Section of mammary tissue from $P$. multocida mastitic cow showing weak protein staining (H\&E, $\mathrm{X} 100)$. 


\section{DISCUSSION}

Mastitis is a multifactor disorder which increases risks of culling of animals and requires understanding of exact mechanism of its pathogenesis. Even though great technological advances have been made, mastitis continues to be a major economic issue for dairy producers, necessitating researchers and dairy advisors continue to refine the recommended mastitis control program (Hussain et al., 2013 and Shaheen et al., 2016). Pasteurella mastitis is not in the center of veterinary attention, although Tabatabaei and Firouzi (2002) mentioned that $P$. multocida is an endemic disease in most countries of Africa. However, the presence of a small number of strains in more than one host species suggests that transmission of bacteria between different host species and it considered as a factor in the population biology of $P$. multocida (Davies et al., 2004).

So the present study aimed to highlight on $P$. multocida as one of the very little recorded and neglected microorganism that affect the lactating mammary gland and its role as one of bacteria that may be involved as an important mastitis pathogen in cows and ewes.

In the current study, it was noticed that $P$. multocida was isolated as single and mixed infection with a percentage of $(3.4 \%)$ and $(11.9 \%)$ in clinical mastitic cows' milk, respectively as well as in mixed forms (13.1\%) from subclinical mastitic cows' milk samples. The isolation rates of $P$. multocida varied in many researches. In the far past, Barnum (1954) reported an outbreak of $P$. multocida mastitis with a severe clinical condition involved 14/20 lowproducing cows. Also, Ribeiro et al. (2010) reported that the uncommon $P$. multocida mastitis in nine dairy cows which milked in the presence of their calves and they noted the low interference of immunosuppressive, predispose factors and absence of pulmonary signs in these animals. Meanwhile, Heleili et al. (2012) isolated P. multocida at a low frequency $(1.51 \%)$ from subclinical mastitic cows.

Moreover, $P$. multocida was isolated in this study from ewes' clinical mastitic milk as a single and mixed infection with CNS (13.6\% for each of them) as well as a single and mixed infection with other bacteria $(6.7 \%$ and $20 \%$, respectively) from subclinical mastitic ewes' milk. Dewani et al. (2002) determined different bacterial species causing ewe mastitis included P. multocida $(6.89 \%)$ which was closely similar to our results in ewe's subclinical mastitis (6.7\%). Also, Al-Majali and Jawabreh (2003) isolated Pasteurella spp. in single and mixed forms from suclinical mastitic ewes. Otherwise, Hawari et al. (2014) isolated 4 P. multocida strains from 40 negative CMT ewe's milk samples. Furthermore, Ahmadi et al. (2014) concluded that P. multocida should be considered as an etiological agent of acute septic mastitis in goats.

Generally, it was noticed that $P$. multocida was isolated from clinical mastitis slightly higher than that from subclinical type in both cows and ewes $(15.3 \%$ versus $13.1 \%$ and $27.3 \%$ versus $26.7 \%$, respectively) as reported previously by Ribeiro et al. (2010). Also, $P$. multocida totally isolated from ewe's mastitic milk with a higher \% than that of cows $(26.8 \%$ versus $13.9 \%$ ) and this may be attributed to a case history of respiratory manifestation in suckling lambs of ewes under this study. This phenomenon was explained by many authors as $P$. multocida is a commensally common organism of the nasopharynx of healthy sheep, goats and calves and it is considered as a primary pathogen, as in case of hemorrhagic septicemia in cattle and a secondary invader in cases with pneumonic lesions (Ewers et al., 2004 and Lainson et al., 2013). Additionally, the reduced hydration of chapped skin decreases lipid content which contains antibacterial fatty acids, bacteriostatic salts, proteins and immunoglobulins as well as decreasing resistance to bacterial colonization (Mavrogianni et al., 2006). Most of the infectious agents can enter the mammary gland in an ascending route via the contaminated skin of the teat or oral cavity of the lambs following sucking (Omalekil et al., 2011). It is possible that the causative organism hide in the mammary gland tissue in a latent form and eventually in case of traumatic teat injuries, the bacteria become infectious and produces the functional and structural abnormality in the affected udder resulting in clinical mastitis (Radostits et al., 2007). More recently, Ahmadi et al. (2014) explained the presence of $P$. multocida in the mammary gland as these bacteria persist either in the environment or within the oral cavity of kids and directly entered the teat canal following sucking or after the entry to the body and the establishment in the target organs being introduced hematogenously to the udder.

ELISA has emerged as a simple important tool for diagnosis as well as monitoring the immune status of animals vaccinated against hemorrhagic septicemia caused by P. multocida in laboratories (Kharb, 2015). We used ELISA as a quick technique for detection of $P$. multocida antibodies in milk whey of unvaccinated animals under this study. These results revealed that, $P$. multocida detected in milk samples by cultural method was lower than its antibodies in milk whey that detected by ELISA technique as a tool of diagnosis; (13.9\%) versus (17. $2 \%$ ) in cow's milk and $(26.8 \%)$ versus $(34.2 \%)$ in ewe's milk. In this aspect, Habashy et al. (2009) found nearly the same difference between traditional $P$. multocida isolation and ELISA technique as they identified $P$. multocida in $26.9 \%, 33.6 \%, 10 \%$ and $50 \%$ of blood samples from diseased and apparently healthy sheep, respectively. 
It was illustrated that both NO and lysozyme were significantly increased according to the grade of mastitis (higher in clinical form than subclinical form) in both cows and ewes and that was agreed with Osman et al. (2010) and Malvisi et al. (2016). These results suggested that the useful use of both $\mathrm{NO}$ and lysozyme for detection of severity and type of mastitis in ewes as well as in cows.

Our results showed that $P$. multocida was isolated from udder tissues of both cows and ewes with $\%$ of $(17.85 \%)$ and $(23.52 \%)$ in single and mixed form, respectively, also the rate of isolation in ewes was higher than that of cows tissues. The most recorded published literatures studied the $P$. multocida effect on lung tissues while scanty data was recorded on mammary tissues but recently Ahmadi et al. (2014) isolated $P$. multocida from infected goat's mammary gland with an unusual acute septic mastitis.

The antibiogram profile of representative $P$. multocida strains isolated from both cows and ewes under this study was showed different susceptibility and resistance for the used antibiotics. It is known that the occurrence of antimicrobial resistance varies between countries and regions Güler et al. (2013). Mevius and Hartman (2000) in agreement with this study recorded no resistance to florfenicol and resistance to TE was reported. Similar observation for CIP sensitivity was noticed by Mohamed et al. (2012). Antimicrobial resistance profiles of $P$. multocida isolates obtained by Khamesipour et al. (2014) nearly similar to our results, they showed that, all the isolates were susceptible to CIP, enrofloxacin, TE and resistance to AM, P, S and AMX at different frequencies.

From the present results, it was noticed that, $P$. multocida isolated from cow's milk showed more resistance to various antibiotics than that isolated from ewe's milk. In agreement with our results, a study of Güler et al. (2013) found that $22 \%$ of isolates were resistant at least for one antimicrobial agent. Among these resistant isolates, the majorities were from cattle strains and only one was from sheep strains. That may be related to more antimicrobial use in cattle populations than in sheep populations generally. Moreover, the high resistance rates against some antimicrobial agents may be due to intensive production systems and common use of antimicrobial in these types of productions.

In studying the mammary cell's DNA integrity using comet assay, it was found that the percentage of damage and DNA \% in comet tail was significantly elevated in case of $P$. multocida infected mammary gland when compared with the uninfected one, $(\mathrm{P}<0.05)$. This was agreed with Praveena et al. (2010) who detected apoptotic nuclei in splenocytes, hepatocytes and infiltrating leukocytes of the lungs in mice experimentally infected with $P$. multocida serotype A1. On the other side, Preuss et al. (2010) showed that toxigenic $P$. multocida strains produce a high mitogenic activity $146 \mathrm{kDa}$ protein toxin (PMT) that blocked apoptosis induced by tumour chemotherapeutic agents in human cancer cell lines, indicated that PMT was a highly potent anti-apoptotic agent, which supported the view of a carcinogenic potential of the toxin.

In the present study, the histopathological features of marked focal and/or diffuse chronic lymphocytic mastitis were described in both cows and ewes which indicated severe tissue damage induced by $P$. multocida as single infection. Mastitis was more severe at the alveolar lumen than in the ducts. These pathological alterations were came in accordance with Hussain et al. (2012); Abba et al. (2014) and Ibrahim et al. (2016) who recorded similar changes in mammary glands of naturally and experimental infected ruminants.

Also, acute mastitis due to $P$. multocida as single infection was described in only two cases of ewes which were characterized by diffuse and severe suppuration with presence of Gram-negative bacteria in the affected udder tissue sections and that came in accordance with results of Ahmadi et al. (2014). Additionally, mixed infection ( $P$. multocida + $S$. aureus) was detected in 10 cases which revealed severe chronic mastitis in the current study.

The ability of $P$. multocida to cause diseases is mainly due to its specific virulence factors as lipopolysaccharide (LPS), outer membrane proteins (OMP), capsule and adhesions, which allow the bacteria to invade the host cells (Boyce et al., 2010 and Wilson and Ho, 2013). LPS is an integral outer membrane component, with a critical role in the disease by interacting directly with innate host immune defense (Omaleki et al., 2011). The OMP enhances the bacterial colonization through its binding to the host extracellular matrix proteins like fibronectin. It also serves as bacterial protective surface antigen and was reported to have a remarkable heterogenicity in different strains isolated from different animal species (Wilson et al., 2011). In vitro studies using ovine mammary epithelial cells have demonstrated that adherence and intracellular localization of bacteria occurs within $10 \mathrm{~min}$, an event considered to be an important step in the development of mastitis (Vilela et al., 2004).

The movement of neutrophils and macrophages during inflammatory process triggered by pathogens determine the severity of the symptoms. PMNs act by destroying the invading bacteria via intracellular granules resulting in release of enzymes, such as $\mathrm{N}$ acetyl-b-D-glucosaminidase (NAGase) and Lactate Dehydrogenase (LDH) (Hussain et al., 2013). The later lead to mammary epithelial damage and thus decrease milk production (Barbano et al., 2006). 
The results of the present study evaluated the cellular and nuclear details of mammary cytological smears; it was possible to diagnose the nature of inflammatory type. This can help to make a preliminary idea about the mode of treatment within a short period. Our findings were similar to those reported by Sangha et al. (2011)

Alkaline phosphatase (AP), a membrane-associated glycoprotein enzyme, increases hydrolysis of phosphate and is located mainly on the outer cellular membranes of alveolar secretary epithelial cells where it helps in active transport processes (Murray and Ewen, 1992). Tissue sections of mammary glands of mastitic animal revealed low or no activity of alkaline phosphatase. In accordance with our results, Silanikove and Shapiro (2007) and EL sayed et al. (2009) have shown that AP is located almost on the mammary epithelial cells apical membrane. This weak activity of AP in mastitic tissues may be related with deactivation of this enzyme owing to negative regulatory process of mammary gland as a result of negative effects of pathogens. The weak activity of alkaline phosphatase enzyme could be due to impaired milk secretory mechanism (Silanikove, 2008).

The weak to negligible activity of protein in tissue sections of mastitic animal in the present study could be due to degenerative changes of mammary epithelium with connective tissue proliferation and impaired activity of endoplasmic reticulum induced by microbial agents. However, different researchers reported that protein staining was decreased (Elsayed et al., 2009 and Hussain et al., 2012). These degenerated mammary cells encompassing the active cellular protein was substituted by the spread of connective tissue under the effect of $P$. multocida which results in poor biosynthetic capacity of udder and decreases cellular differentiation (Hussain et al., 2013).

\section{CONCLUSION}

From this study, it was concluded that $P$. multocida should be considered as an important sharing etiological agent of mastitis in both cows and ewes which causes a significant pathological alteration in the glandular structure. ELISA was considered as a quick and reliable technique for detection of $P$. multocida infection in the mammary gland especially in the un-vaccinated farms beside the traditional cultural method. The cytological interpretation is quiet helpful in rapid screening of the mammary gland affections. Histochemical data showed weak alkaline phosphate activity and low protein staining density in tissues sections of mastitic animals that reflecting impaired activity. The DNA integrity of mammary gland cells was declared using comet assay. These observations strongly support the belief that mastitis lead to losses in mammary gland function and that were directly related to disruption of alveolar cell DNA integrity, sloughing of cells, necrosis with a consequent fibrosis and an increase in the inflammatory cells.

\section{REFRENCES}

Abba, Y.; Adamu, L.; Igbokwe, I.O.; Hassan, S.U. and Sule, D. (2014): Effect of clinical mastitis on the gross morphometry and histopathology of mammary glands of Sahel goats. Int. J. Livestock Res., Dec 14, 23:24.

Afzal, M.; Muneer, R. and Akhtar, S. (1992): Serological evaluation of Pasteurella multocida antigens associated with protection in buffalo calves. Rev. sci. tech. Off. int. Epiz., 11 (3): 917-923.

Ahmadi, N.H.; Yazdil, H.S.; Derakhshandeh, A. and Gha, M. (2014): Acute mastitis caused by pasteurella multocida in a goat: clinicopathological and microbiological findings. Braz. J. Vet. Pathol., 7 (1): 25-28.

Ajuwape, A.T.P.; Roberts, A.A.; Solarin, O.O. and Adetosoye, A.I. (2005): Bacteriological and haematological studies of clinical mastitis in goats in Ibadan, OYO state, Nigeria. 60: 307310.

Al-Majali, A.M. and Jawabreh, S. (2003): Period prevalence and etiology of subclinical mastitis in Awassi sheep in southern Jordan. Small Rum. Res., 47 (3): 243-248.

Barbano, D.M.; Ma, Y. and Santos, M.V. (2006): Influence of raw milk quality on fluid milk shelf life. J. Dairy Sci., 89:15-19.

Barnum, D.A. (1954): A Herd outbreak of mastitis caused by Pasteurella multocida. Can. J. Comp. Med. Vet. Sci., 18(4): 113-119.

Boyce, J.; Harper, M.; Wilkie, I. and Adler, B. (2010): Pasteurella. In: Pathogenesis of bacterial infections in animals, ed J. F. Prescott, Blackwell Publishing, IA, USA.

Cohen, M.; Bohling, M.W.; Wright, J.C.; Welles, E.A. and Spano, J.S. (2003): Evaluation of sensitivity and specificity of cytologic examination: 269 cases (1999-2000). J. Am. Vet. Med. Assoc., 1; 222 (7): 964-7.

Confer, A.W. (1993): Immunogens of Pasteurella. Vet. Rec. 37 (3-4): 353-68.

Davies, R.L.; MacCorquodale, $R$. and Reilly, $S$. (2004): Characterisation of bovine strains of Pasteurella multocida and comparison with isolates of avian, ovine and porcine origin. Vet. Microbiol., 99:145-158.

Dewani, P.; Rind, $\quad$ R. and Bhutto, B. (2002): Bacteriological studies on mastitis in ewes and goats. J. Anim. Vet. Advances., 1 (2): 98-100.

Elsayed, E.H.; EL-Shafie, M.H.; Saifelnasr, E.O.H. and Abu El-Ella A.A. (2009): Histological and 
histochemical study on mammary gland of Damascus goats through stages of lactation. Small Rum. Res. 85:11-17.

Eugene, W. (2007): The prevalence of mastitis in small ruminants and the effect of mastitis on small ruminant production. NMC annual meeting proceedings (2007) the prevalence of mastitis IN.

Ewers, C.; Lübke-Becker, A. and Wieler, L.H. (2004): Pasteurella: insights into the virulence determinants of a heterogenous bacterial type. Berl. Munch. Tierarztl. Wochenschr., 117: 367-386.

Güler, L.; Gündüz, K. and Sarişahin, A.S. (2013): Capsular typing and antimicrobial susceptibility of Pasteurella multocida isolated from different hosts. Kafkas Univ. Vet Fak Derg., 19 (5): 843-849.

Habashy, H.F.; Fadel, N.G. and El Shorbagy, M.M. (2009): Bacteriological and pathological studies on the causes of mortalities among sheep in Sharkia-Governorate farms. Egypt. J. Comp. Path. \& Clinic. Path., 22 (1): 130-146.

Hawari, A.D.; Obeidat, M.; Awaisheh, S.S.; AlDaghistani, H.I.; Al-Abbadi, A.A.; Omar, S.S.; Qrunfleh, I.M.; Al-Dmoor, H.M. and ElQudah, J. (2014): Prevalence of mastitis pathogens and their resistance against antimicrobial agents in Awassi sheep in AlBalqa Province of Jordan. Am. J. Anim. Vet. Sci., 9 (2): 116-121.

Heleili, N.; Ayachi, A.; Melizi, M.; Kassah, A.L. and Mamache, B. (2012): Prevalence of subclinical bovine mastitis and the in vitro sensitivity of bacterial isolates in Batna Governorate, East of Algeria. J. Anim. Sci. Adv., 2(6): 576-582.

Henery, R.F. (1974): Clinical Chemistry Principles and Techniques. $2^{\text {nd }}$ Ed., Harper and Row, Hagerstein, M.D.

Hussain, R.; Khan, A.; Javed, M.T. and Rizvi, F. (2012): Possible risk factors associated with mastitis in indigenous cattle in Punjab, Pakistan. Pak. Vet. J., 32(4): 605-608.

Hussain, R.; Khan, A.; Javed, T.M. and Ali, F. (2013): Morphometric and pathological studies on mammary gland of slaughtered Nile- River buffaloes. Pak. J. Agri. Sci., 50 (1): 123-130.

Hussain, R.; Javed, M.T.; Khan, A.; Mahmood, F. and Kausar, R. (2012): Mastitis and associated histo-pathological consequences in the context of udder morphology. Int. J. Agric. Biol., 14: 947-952.

Ibrahim, H.H.; Jesse, F.F.A.; Abba, Y.; Chung, E.L.T.; Marzai, A.D.; Haron, A.W.; ZamrSaad, M.; Omar, A.R. and Saharee, A.A. (2016): Clinical and histopathological study on reproductive lesions caused by Pasteurella multocida type $\mathrm{B}_{2}$ immuonogens in buffalo hifiers. Bulgarian J. Vet. Med.

Khamesipour, F.; Momtaz, H. and Mamoreh, M.A. (2014): Occurrence of virulence factors and antimicrobial resistance in Pasteurella multocida strains isolated from slaughter cattle in Iran. Frontiers in Microbiol. Infec. Dis., 5 (10) Article 536: 9 pages.

Kharb, S. (2015): Development of ELISA techniques for haemorrhagic septicaemia. Int. J. Bioassays. 4(11): 4574-4577.

Lainson, F.A.; Dagleish, M.P.; Fontaine, M.C.; Bayne, C. and Hodgson, J.C. (2013): Draft genome sequence of Pasteurella multocida A: 3 Strain671/90. Genome Announc., 1: 803813.

Malvisi, M.; Stuknyte, M.; Magro, G.; Minozzi, G.; Giardini, A.; De Noni, I. and Piccinini, R. (2016): Antibacterial activity and immunomodulatory effects on a bovine mammary epithelial cell line exerted by nisin A-producing Lactococcus lactis strains. J. Dairy Sci., 99 (3): 2288-96.

Mavrogianni, V.S.; Cripps, P.J.; Papaioannou, N.; Taitzoglou, I. and Fthenakis, G.C. (2006): Teat disorders predispose ewes to clinical mastitis after challenge with Mannheimia haemolytica. Vet. Res., 37: 89-105.

Mevius, D.J. and Hartman, E.G. (2000): In vitro activity of 12 antibiotics used in veterinary medicine against Mannheimia haemolytica and Pasteurella multocida isolated from calves in the Netherlands. Tijd Dierg, 125: 147-152.

Mohamed, M.A.; Mohamed, M.W.; Ahmed, A.I.; Ibrahim, A.A. and Ahmed, M. S. (2012): Pasteurella multocida in backyard chickens in Upper Egypt: incidence with polymerase chain reaction analysis for capsule type, virulence in chicken embryos and antimicrobial resistance. Vet. Ital., 48:77-86.

Muneer, R. and Afzal, M. (1989): Preliminary studies on improved oil-adjuvant vaccine for haemorrhagic septicaemia in buffalo calves. Rev. sci. tech. Off. int. Epiz., 8 (4): 999-1004.

Murray, G.I. and Ewen, S.W. (1992): A new fluorescence method for alkaline phosphatase histochemistry. J. Histochem. Cytochem., 40: 1971-1978.

National Committee for Clinical Laboratory Standards (NCCLS) (2008): Performance Standards for Antimicrobial Disk and Dilution Susceptibility Tests for Bacteria Isolated from Animals; Approved Standard, $2^{\text {nd }}$ Edn. NCCLS Document M31- A3.Wayne, PA: National Committee for Clinical Laboratory Standards.

Omaleki, L.; Browning, G.F.; Allen, J.L. and Barber, S.R. (2011): The role of Mannheimia species in ovine mastitis. Vet. Microbiol., 153: 67-72.

Osman, K.M.; Hassan, H.M.; Ibrahim, I.M. and Mikhail, M.M. (2010): The impact of Staphylococcal mastitis on the level of milk IL-6, lysozyme and nitric oxide. Comp. Immunol. Microbiol. Infect. Dis. 33 (1): 8593. 
Owens, F.N.; Secrist, D.S.; Hill, W.J. and Gill, D.R. (1997): The effect of grain source and grain processing on performance of feedlot cattle: a review. J. Anim. Sci., 75 (3): 868-879.

Pawar, Y.; Kadam, D.; Khandekar, G. and Nehte, R. (2015): Gross and cytological evaluation of canine spontaneous mammary neoplasms and its correlation with histopathology and morphometric analysis. Int. J. Vet. Sci., 4 (3): 104-110.

Preuss, I.; Hildebrand, D.; Orth, J.H.; Aktories, K. and Kubatzky, K.F. (2010): Pasteurella multocida toxin is a potent activator of antiapoptotic signalling pathways. Cell Microbiol., 12(8):1174-85.

Praveena, P.E.; Periasamy, S.; Kumar, A.A. and Singh, N. (2010): Cytokine profiles, apoptosis and pathology of experimental Pasteurella multocida serotype A1 infection in mice. Res. Vet. Sci., 89(3):332-339.

Quinn, P.J.; Markey, B.K.; Leonard, F.C.; FitzPatrick, E.S.; Fanning, S. and Hartigan, P.J. (2011): Veterinary Microbiology and Microbial Disease. 2nd ed., Wiley-Blackwell, J Wiley and Sons Ltd Publication, UK.

Radositis, O.M.; Gay, C.C.; Hinchcliff, K.W. and Constable, P.D. (2007): Veterinary Medicine A Textbook of the Diseases of Cattle, Horses, Sheep, Pigs, and Goats. London: Saunders Elsevier, 673-762.

Rajarman, V.; Nonnecke, B.J.; Franklin, S.T.; Hamell, D.C.; Horst, R.L. (1998): Effect of vitamin $\mathrm{A}$ and $\mathrm{E}$ on nitric oxide production by blood mononuclear leukocytes from neonatal calves fed milk replacer. J. Dairy Sci., 81: 3278-3285.

Ribeiro, M.G.; Lara, G.H.B.; Fernandes, M.C.; Paes, A.C.; Motta, R.G.; Siqueira, A.K.; Salerno, T. and Listoni, F.J.P. (2010): Bovine mastitis by Pasteurella multocida: a study of nine cases. Arq. Bras. Med. Vet. Zootec., 62 (4): 985-988.

Rimler, R.B. and Rhoades, K.R. (1989): Pasteurella multocida. Adlam, C.; Rutter, J.M. Eds. Pasteurella and pasteurellosis. London: Academic Press. 37-73.

Sangha, S.; Singh, A.; Sood, N.K. and Gupta, K. (2011): Specificity and sensitivity of cytological techniques for rapid diagnosis of neoplastic and non-neoplastic lesions of canine mammary gland. Braz. J. Vet. Pathol., 4(1): 13-22.

Shaheen, M.; Tantary, H.A. and Nabi, S.U. (2016): A Treatise on bovine mastitis: Disease and disease economics, etiological basis, risk factors, impact on human health, therapeutic management, prevention and control strategy. J. Adv. Dairy Res., 4 (1): 10 pages.

Schltz, L.A. (1987): Veterinary Haematology. 3rd ed., Lea and Febiger. 39 (2): 217-222.

Sendecor, G.W. and Cochran, W.G. (1989): Statistical Methods. Eighth Edition, Iowa State, University Press, 503 p.

Silanikove, N. (2008): Milk lipoprotein membranes and their imperative enzymes. Adv. Exp. Med. Biol., 606:143-161.

Silanikove, N. and Shapiro, F. (2007): Distribution of xanthine oxidase and xanthine dehydrogenase activity in bovine milk: physiological and technological implications. Int. Dairy J., 17 (10): 1188-1194.

Singh, N.P.; McCoy, M.T.; Tice, R.R. and Schneider, E.L. (1988): A simple technique for quantitation of low levels of DNA damage in individual cells. Exp. Cell Res., 175 (1): 184191.

Suvarna, K. S.; Layton, C. and Bancroft, J. D. (2013): Bancroft's Theory and Practice of Histological Techniques, by Suvarna, 7th Edition Churchill Livingstone.

Tabatabaei, H. and Firouzi, A. (2002): Livestock Bacterial diseases, Publications University Tehran, pages 330-335.

Vilela, C.L.; Fitzpatrick, J. and Morgan, K.L. (2004): In vitro adherence and invasion of ovine mammary epithelium by Mannheimia (Pasteurella) haemolytica. Vet. J., 167: 211213.

Wilson, B.A. and Ho, M. (2013): Pasteurella multocida: From zoonosis to cellular microbiology. Clin. Microbiol. Rev., 26: 631655

Wilson, B.A.; Salyers, A.A.; Whitt, D.D. and Winkler, M.E. (2011): Bacterial pathogenesis: A molecular approach, 3rd edn, American Society for Microbiology (ASM). 


\section{بعض الدراسات علي الباستيريلا مالتوسيدا كمسبب لإلتهاب الضرع في الأبقار والنعاج الحلابه \\ هناء عبل المنعم عبل الفتاح عصفور، عبير محد أنور، أثرف نبيه محد ، عبيرالسبي عبل الفتاح المتولى}

Email: hanaaasfour@yahoo.com Assiut University web-site: www.aun.edu.eg

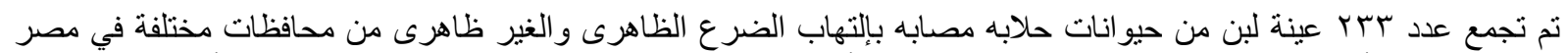

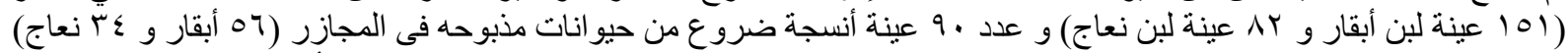

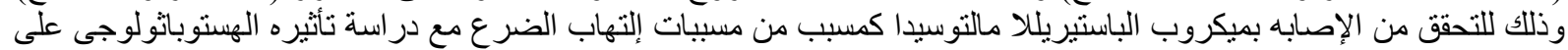

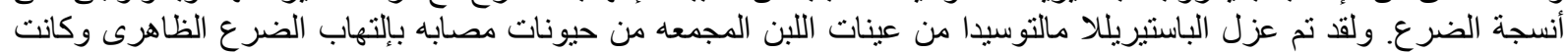

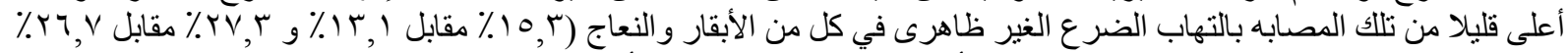

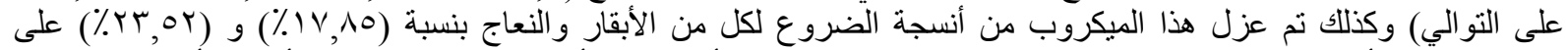

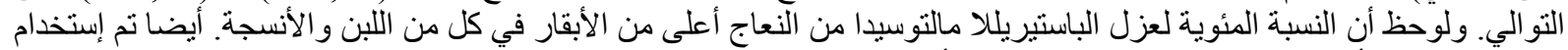



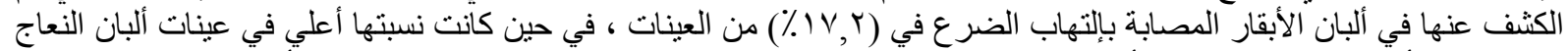

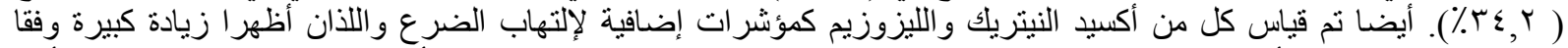

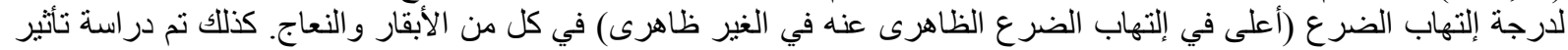

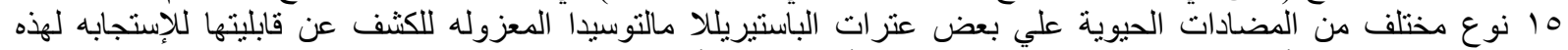

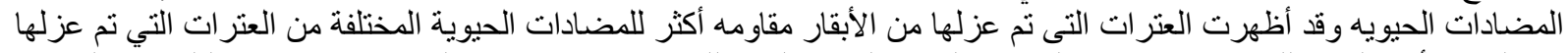

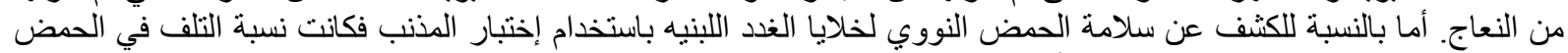

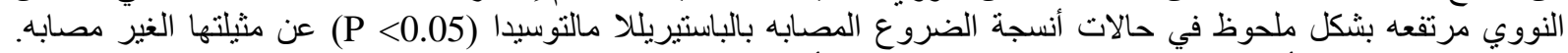

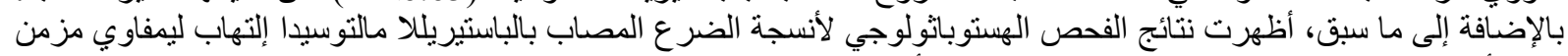

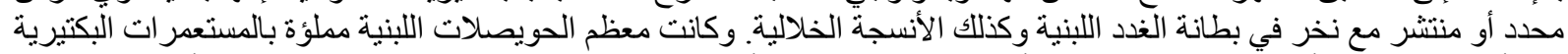

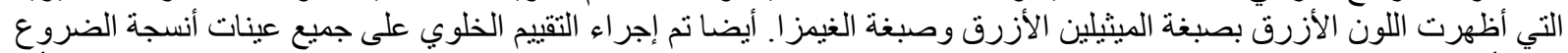

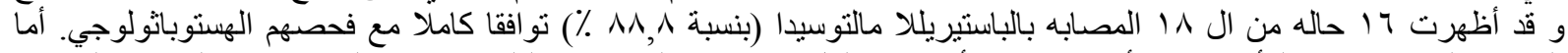

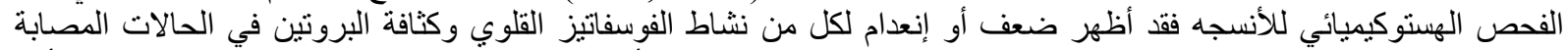

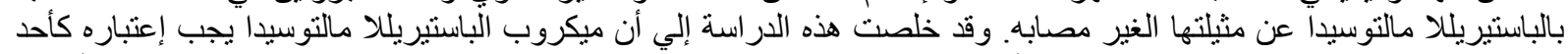

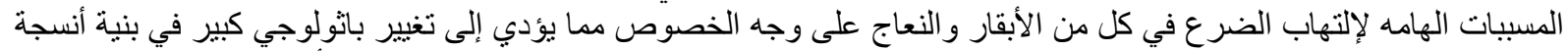

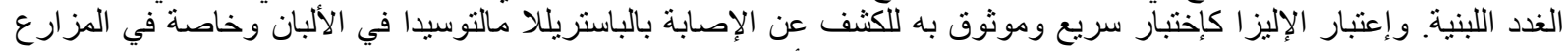

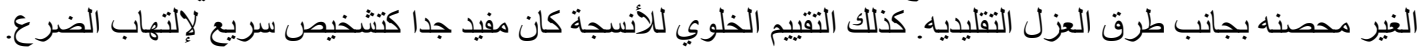

